\title{
Speech(lessness), Negative Pleasure, and the Sublime Objects of Suburbia in Ben Lerner's The Topeka School
}

\section{Abstract}

Lerner's The Topeka School references "the twenty-four-hour news cycle, Twitter storms, algorithmic trading," (24) as a version of the debate strategy of the spread in the post-truth United States. In a similar way, the incessant and supernumerary presence of suburban objects in the novel functions as a spread the characters continuously have to face. Linking the spread and the sublime, this essay examines how the novel intertwines the characters' responses to their suburban home with their subsequent futures on their way into the Trumpian post-truth age. Informed by the Kantian sublime, it shows how the sublime of the spread denies negative pleasure as the denouement of the threat of the sublime. The essay develops the argument that Lerner's novel frames the ability to linguistically respond to the paradoxically placing and displacing effect of the sublime of the spread as a tool that on the one hand can help them navigate their 1990ssuburban life, but on the other hand also foreshadows their response to further paradoxical displacement in the post-truth era.

Keywords: sublime, contemporary, American studies, American sublime, 21st century, objectoriented ontology, post-truth, suburban culture

Ben Lerner's 2019 novel The Topeka School is a retrospective that seeks a semblance of the Trump-age United States in the past and vice-versa. It examines the modes of growing up as a white, male teenager in the late-1990s suburban United States. As an account of the protagonist Adam Gordon's teenage years in Topeka, Kansas, presented as written by himself and his 
parents, respectively, in the late 2010s, the novel provides a portrait of the kind of rural American boyhood that, in Adam's eyes, is a central backdrop of the post-truth age of fragile masculinities and poisoned political stalemates in the U.S. Early in the novel, Adam already imagines "looking back on the [late 1990s] from a vaguely imagined East Coast city where his experiences in Topeka could be recounted only with great irony" (17). However, as it turns out when his East Coast vision comes true some twenty years later, his experiences in Topeka are not so much some awkward accidents of coming-of-age that could be ironically shrugged off, but rather a foreshadowing of the continuous struggle of finding an individual voice amidst the post-truth discourse.

Many reviews of the novel highlight the role that it assigns to discrepancies in education and linguistic ability in the development of post-truthism and its repercussions for identity development (Day; cf. Hallberg; cf. Preston). Employing the concept of the sublime as a source of "negative pleasure" (Kant 98; par. 23) in this essay, I read those discrepancies in conjunction with the young protagonists' debilitations in the face of an environment that overwhelms them.

The sublime in the novel is framed as the spread, a term borrowed from debate terminology, denoting an overwhelmingly rapid and trenchant outpour of argumentative prose (23-24) against which an opposing debater stands little chance. The connection between the spread and the sublime provides two arguments. The first one holds that the sublime of the spread differs from the Kantian sublime in that it stops at the moment of debilitation, which for Kant is merely a side effect on the way to negative pleasure. The difficulty of arriving at this moment of negative pleasure after facing the debilitating sublimity of the spread, then, is a central conflict of the novel that it shares with the challenge of facing the spread as modus operandi of post-truth public debate.

The second argument contends that this conflict is negotiated around the idea that language can provide a tool to surmount the debilitating effect of the spread, which the novel illustrates in the characters of Adam Gordon and Darren Eberheart. Furthermore, it illuminates the ambiguity of Kant's labeling the pleasure of the sublime negative: not only is the existential threat of the sublime a debilitation that is confrontable via language, but language as the medium that dissolves this confrontation is a reaction to the displacement of the subject into the unfamiliar sphere of the transcendence of the sublime object. Thus, the Kantian sublime, as well as the sublimes of the 
spread and post-truth discourse, are modes that facilitate a paradoxical placement through displacement executed through linguistic apprehension of the sublime experience.

As Kant's sublime objects temporarily overwhelm the human subject, the spread is meant to overwhelm the opposing party with a seemingly infinite outpour of information, and it has found its way into contemporary everyday life, as e.g. "the spoken warnings at the end of the increasingly common television commercials for prescription drugs, when risk information [is] disclosed at a speed designed to make it difficult to comprehend ..., the twenty-four-hour news cycle, Twitter storms, algorithmic trading, spreadsheets ... DDoS attacks" (Lerner 24). While the idea of unsurmountable vastness is also contained in the sublime of the American landscapes of nineteenth-century literature and visual art (Baker 309), in the novel, it complements a sublime of similar cityscapes and simultaneous life in American suburbia, and thus emanates no longer from trees stretching across hills and mountain ranges but from the superfluity of suburban conveniences, like groceries stacked on shelves that run into the infinite distance of a Topeka Hypermart (Lerner 130), or prefabricated houses spreading across suburbia throughout the United States.

The Kantian sublime and the superfluous suburban conveniences of the late-1990s Topeka show striking resemblances to the spread. The spread mirrors the form of the Kantian sublime object, but it turns the effect of judging such objects inside out: temporary mental inhibition and Kantian negative pleasure, are substituted with utter, and final, inability to act facing the spread. As regards the form of sublime objects, they, for Kant, need to bear appearances "whose intuition carries with them the idea of infinity" (Kant 112; par. 26), which in turn threatens to overwhelm the mind's capacity for reason with an inhibiting effect ( Kant 98; par. 23). This subsequently culminates in a "negative pleasure" (Kant 98; par. 23): a threatening of reason and ability to act and think beyond the sublime object (hence the modifier negative) which turns into the pleasure of realizing that even the ability to conceptualize the idea of the object's sublimity is evidence of transcendental capability, and thus of an intimate connection with the seemingly transcendent sublime object and a liberation from contingency.

The crucial difference between the Kantian sublime and the spread lies in the effect the spread is intended to have on the subject facing it. The source of the spread, as it were, is an infinite 
reservoir of counterevidence whose dam may be broken in case anyone dared oppose one's own opinion, not only in a formal debate environment: a superabundance of similar pieces of information simultaneously unleashed to crush opposition, they are a resource for asserting one's own power over differing voices. The spread thus becomes a form of the sublime whose effect on the subject is not transcendental rejoicing but utter disability: negativity, as it were, without pleasure.

In this function, the sublime infinity of information and its disabling effect on others if canalized in the spread may be regarded a central component of the post-truth age: a cultural situation in which the very notion of truth has lost its meaning, and which is characterized by ideological compartmentalization of society exacerbated by the aforementioned forms the spread can take (Arias-Maldonado 1-7). Or, in terms of the spread, there is no objective truth that could calibrate a discourse if the outcome can be steered as easily by breaking whichever dam of information to assert the validity of one's own vantage point. To break the logic of 21 st-century post-truthism, then, is to break the logic of the spread.

To be a subject here was to be spread by objects," (130; emphasis added) Adam thinks while at a local Hypermart; the adolescents in Lerner's novel are continuously being spread by suburban objects - houses, groceries, streets, high school routine, high school parties, supermarkets constantly facing the oppressive force of the sublimity that lurks behind the suburban façade. Just as the spread overwhelms a subject with an outpouring of information, the similar houses, stores, and routines incessantly confront the adolescents of the novel. Some of the young Topekans succeed in finding their way - or voice, or language - in this environment by resorting to the mode of the spread itself and consciously, comprehensively, and poetically expressing the sublime experience, and some of them fail and lose themselves in this fishnet.

These processes are negotiated and juxtaposed in the novel by the characters of Adam Gordon, an eloquent, poetic know-it-all high school jock and debate prodigy born to two New-York psychiatrists who moved to Kansas to work for a psychiatric institution called the Foundation; and Darren Eberheart, a shy outsider and underachiever who is, as a mocking project, inaugurated into the cool kids' circle, which leads to the incident referenced throughout the novel - a fight Darren picks at a party and during which he severely injures a young girl. 
The third-person limited narration focalized through Adam, in the chapters narrated by himself, continuously extracts his thoughts about his upbringing in Topeka and emphasizes his sense of poetic, educated middle-class meta-awareness of his own situation. This awareness develops into a characteristic that distinguishes him from Darren over the course of the novel, and it is a feature permeating Adam's entire life, from his fascination with poetry to his success as a debater. Moreover, Adam, born into a family of academics, and to a mother who is not only a successful psychiatrist but also a famed author, and Darren, born to a single-mother nurse, depict polar opposites with regard to educational backgrounds. In addition, the care and attention of Klaus, his parents' intellectual Jewish colleague, and the wealth, not only of information, which Adam enjoyed during his upbringing, constitute the root of his broad intellectual horizon and preoccupation with thinking.

The role of such an exposure to the liberal arts and their role for the advance of post-truthism is emphasized in 2019 by Wendy Brown, in her work In the Ruins of Neoliberalism, where she states that: "neoliberalism's relentless diminution of nonmonetized existence, such as being knowledgeable and thoughtful about the world, converged with the privatization choking off access to higher education for the many. A generation turned away from liberal arts education was also turned against it" (6). It is the awareness arising out of education like Adam's that the novel sets as the precondition for the enunciation of resistance against the debilitating effect of the sublime spread, of a sense of direction and control over their lives. Furthermore, the novel contrasts Adam's ability to, as it were, spread his environment through thinking about it, with Darren's inability to position himself.

Rewinding into the 1990s setting of the novel, twenty-four-hour news cycles and twitter storms seem far removed from the narrated world, but the teenage protagonists find themselves entangled in a similar network, which is the rural-suburban environment they grew up in. The very first scene of the novel introduces both Adam and the sublime of the novel's suburban setting, along with the imposing superabundance of its components. Rambling on, lost in his own thoughts, Adam does not realize his girlfriend has slipped off the boat on Lake Sherwood they were spending the evening on. Searching for her on the shore, he enters the house he thinks is his girlfriend's. However, deceived by "the level of familiarity and flatness" (10) the McMansions on Lake 
Sherwood all share, he does not recognize the tiny differences that could have shown him that he actually trespassed into someone else's house, so that "with his recognition of its difference, was a sense, because of the houses' sameness, that he was in all the houses around the lake at once; the sublime of identical layouts" (10).

This realization does not only turn into the terror of unwillingly trespassing into someone else's most private environment, but it also instigates a deindividualizing, de-corporealizing experience for Adam, in which he finds himself at once trapped in a suburban cage; one resembling the other and detached from the scene that is like an artificially created landscape of a miniature train set. (cf. 10), "he was frozen in fear in this particular bathroom and in all the bathrooms simultaneously; he looked down from a hundred windows at the little boat on the placid man-made lake" (11). Adam's experience of the sublime plenitude of McMansions here exhibits the same effect the sublime of the post-truth spread has on the individual: upon realization of the sublime, what follows is not a binding of his subjectivity to the transcendence of the sublime object in negative pleasure, but a detachment of his subjectivity from it. The superabundance of similar mansions sparks an estrangement that removes Adam from the scene, and instead of a Kantian denouement of the moment of facing the sublime, a "stronger outpouring of [vital force]" (98; par. 23), what follows is the threat of total disability inherent in the sublime of the spread:

He felt like a timer had started somewhere, that he had minutes, maybe only seconds, to flee the house into which he'd unintentionally broken before someone emptied a shotgun into his face or the cops arrived to find him hovering outside the bedroom of a sleeping girl.... now the little differences called out to him as he descended... (11)

Although this episode has not yet ended in negative pleasure, Adam at least achieves to remove himself from the oppressing situation both intellectually and physically by fleeing the house. Yet it is his constant cognitive involvement with the situation that leads him to the realization that he must act in order to escape the debilitating overpresence of the sublime. It pushes him into assuming agency, which, at this stage of the novel, leads to a disoriented attempt of escaping the oppressiveness of the sublime by looking for his car (cf. 12). When he has finally found it, he is "overjoyed," (12) and "the sound of the doors unlocking [is] deeply reassuring" (12). He has 
surmounted the debilitation to arrive at the moment of pleasure in his relief when he finally also spots his girlfriend.

The successive mechanisms of deception, realization, and correction are the central structure of this scene, which becomes a type for several other scenes Adam and Darren find themselves in. However, for Darren, the progression already stops at the deceptive stage, and the adverse consequences of his inability to perceive the nuancing of his environments and to abstract his own position amongst them, in order to navigate them, cements this inability as the key lack the novel diagnoses him with. The novel provides a counterpart to the above scene in which Darren experiences a sublimity, not unlike the one experienced by Adam. One evening, Darren finds himself invited to a lakeside party several miles outside of Topeka, but when the popular seniors who dragged him there drive back, they leave him on the shore, intoxicated, and he wakes up alone the next day with no choice but to wander through rural Kansas in search for the way back home. While at first, it is "a comfort to Darren that the scenery is looped" (153), and he feels like he was reeling off the same tape over and over again at the speed of his own strides (cf. 154), the similarity becomes depressing, enveloping him, and filling him with the anticipation that "his surroundings, which are familiar as all prefabricated construction must be, will soon coalesce into an area of Topeka" (154). The entire scene is somewhat reminiscent of the pre-CGI days of film, as if Darren was on a stage whose background is but a single piece of linen painted with one single scenery that rolls along on a giant barrel to simulate movement as the actor pretends to be walking away from the location of the previous scene without changing his position, an illusion of movement. He does not reach Topeka, but he is relieved to be released from the loop of rural suburbia when "the architecture around him grows particular enough to be unfamiliar and not uncanny in the way of chains," (155) and he struggles for words to describe "his relief at being lost, but in this world, not one like it" (155).

In this scene, Darren's inability to cope with the pressing uncanniness of the surroundings that spread him becomes strikingly apparent when examined under the lens of the progression of deception, realization, and correction. Unlike Adam in this situation, Darren does not break out of the deceptive state since he is not sufficiently involved in thinking about his situation, instead relying on the hope that the suburban façade is soon going to turn out to be Topeka (cf. above). 
Loath to take matters into his own hands, or mind, he waits for his situation to resolve itself. While Adam can abstract and reflect on his own position to take action when he realizes that he has been deceived by the similarity of the Lake Sherwood mansions, Darren, shielding himself, dives deeper into the similarities, entertaining himself with the idea of being able to "slow down or speed up ... the tape" (154) as which he regards his aimless wandering. As a consequence, he does not recognize the nuances in the reality of the suburban homes he passes by, and instead intensifies his being lost in the suburban stage he found himself in until the nuances are so apparent that he acknowledges them as worthy of being recognized as differences - a point at which he is already lost and unable to continue by himself. Adam's success at regaining his agency at Lake Sherwood, however, shows that in truth only the breakout Darren cannot facilitate by himself would provide him with relief and the power to decide his own path, leaving Darren to rely on finding a payphone (cf. 155), diminishing his agency to the act of begging for help.

In a later scene, Adam consciously realizes the role language could play in overcoming the debilitation of the spread. When Adam joined his mother and grandmother at the Topeka Hypermart for grocery shopping, he wandered off between the aisles "and [entered] a vast aisle of protein mixes and tubs of vitamins and other products and experienced as he watched the packaging repeat into the distance a thrill not unlike what he'd felt in the wrong McMansion on Lake Sherwood, that banal but supernumerary sublime of exchangeability" (130). The superabundance of products and their stretching into seeming infinity on the Hypermart shelves induced another instance of Adam facing a sublime that spreads him. What follows is a surrealist vision similar to the one he had had at the lake. But this time, it transcends the threatening and oppressive effect it had in the lake neighborhood. In addition to letting him assess his own situation as a subject facing the sublime, Adam's uncanny abstraction revealed to him the tools of poetry, of language, as a way of reasserting his own ability:

Adam could sense that all of the materials inside the packaging ... had reverted into a kind of putty, a kind of gum, an abstract stuff out of which they'd have to make new languages, new bodies. ...

The products withdraw into the walls ... Now we see a procession of wheeled things: ... large plastic tubs of evidence that, if read quickly, reverts to stuff in the mouth: putty, poetry. (133) 
The idea that the sublime is inviolably connected with language and poetry is hardly a peculiarity of the novel, but a foundation of the philosophical reception of the sublime itself. Indeed, both the "power of conceiving impressive thoughts" (Russell xii) and a "certain distinction and excellence in expression" (Pseudo-Longinus 43) are bedrocks of the rhetoric "transport ${ }^{\lfloor 1]}$ (43) triggered by the sublime.

Both impressive thoughts and excellence in expression are key characteristics of Adam. As John Day points out in his review of the novel, "Adam is exactly the kind of person who would think of the 'sublime of identical layouts' when he has wandered into a stranger's house" (Day), but Darren struggles to pin down his affective response to both the similarities in rural suburbia and the breaking of their pattern, which lets the lucid, differentiating free-indirect discourse that permeates Adam's initial scene - "[i]n a single shudder of retrospection his impressions of the house were changed: ... the carpet on the stairs - wasn't the pile too tick, too dark in the dark to have been truly white?" (10) - wither into a rudimentary, quite literal, speechlessness during Darren's wandering: "There should be a word for the relief he feels" (155). Darren eventually succumbs to the might[ ${ }^{2]}$ of the spread.

In contrast, Adam's attempt to grasp the sublime, albeit not yet processed into a linguistically coherent response at the lake neighborhood, constitutes the foundation of his further realization of the power he has through his linguistic prowess. Adam's Hypermart realization that the debilitating sublime objects he faces are the source of their own undoing - should their effects be verbalized is a pivotal point for Adam in the novel. It reassures him that even by facing the twisted sublimity of an environment that follows the logic of the debilitating spread, he can evade the grip of its disabling outpouring through linguistically framing his experience. His linguistic prowess turns out to be not merely a bore to his girlfriend or a challenge to his parents, but it now constitutes a conscious way out of the grasp of the sublime spreads of supernumerary, virtually identical McMansions or Hypermart products. The spread as an offensive debating technique turns into a defensive mode of retaining agency. Instead of being overwhelmed, language now in turn can transfix these objects in their sublime oppressiveness and open up the possibility of turning the debilitating moment of their spread into Kantian negative pleasure. Similar to how negative 
pleasure constitutes a feeling of liberation from contingency, Adam's ability to overcome the spread endows him with agency.

However, the sense of agency comes with another twist: simultaneously with substituting agency for debilitation, it substitutes uncanny familiarity with frightening displacement. Although Adam actively breaks out of the objects' deception and realizes he is in the wrong house before the disaster strikes, this experience suddenly displaces him, not revealing to him whose house he has ended up in. Although it argues, in part, against Kant, Timothy Morton's conclusion on sublime objects is similar to this logic of displacement:

This is no man's land. But it's not a bleak nothingness.... No. This is a crowded Tibetan zoo, an Expressionist parade of uncanny, clownlike objects. We're not supposed to kowtow to these objects as Burke would wish. Yet we're not supposed to find our inner freedom either (Kant). It's like one of those maps with the little red arrow that says You Are Here, only this one says You Are Not Here. (226)

However, the logic of displacement is not an alternative to Kantian freedom in the novel, but rather its component. Displacement, as it were, is the only state in which the sublime, or the spread, can induce negative pleasure.

This becomes evident in Adam's McMansion episode. In Kantian metaphysics, and in Romanticism, this principle is the logic of the transcendence of nature in the moment of the apprehension of its sublimity. In the novel, transcendence is a stranger's house; for the Romantics, it is the photographic negative of nature, Shelley's "clear universe of things" (line 40); but would it not be more convenient for us to get a glimpse of it in our own house? The Kantian solution here seems to be that in order to gain an idea of the stranger's house, the mind focuses on the resemblances it can find of it in its own dominion, but the price it has to pay for this is a momentary displacing, a clumsy stumbling into the stranger's house just to evacuate it again immediately. Abort the mission to succeed! Yet, should we find our way out of that unfamiliar environment, the negative of our own one, what awaits is pleasure. Similarly, Adam's agency comes at the price of displacement. Negative pleasure, then, is not only negative in the sense that it arises out of an existential threat, but also in the sense that it allows for Kantian pleasure, or Adam's agency, only 
in an environment that is in some way the photographic negative of where the mind thought it was before.

As his Hypermart episode reveals to Adam, what re-places him to an environment he can act within is poetry, the power of language canalized against the overwhelming negative of the debilitating spread. It is this task all adolescents in the novel are facing, and also the key to the magical realism of Adam's overintellectualized episodes. Only if the glimpse of the sublime in the negative is manifested in themselves in their own poetic recapitulation of the sublime experience, can they find their way back out of the negative and grow up with a sense of agency, a task which Adam tries to live up to and which Darren kowtows to. To be a subject, now, is to spread back at objects.

In the penultimate chapter of the book, these two modes of reacting to the sublime clash at a house party that Adam and Darren both attend weeks after graduation. While Adam, for the first time, achieves to consciously control his agency in the sublime moment during a rap battle, the occasion turns into Darren's demise. Drunk and high, both find themselves in a circle, in Adam's friend Jason's garden, arm in arm with their school mates, fighting each other with impromptu lines to nonexistent beats in a kind of rap battle, "[rhyming] about bitches and gun play" (256). Sublime objects have now taken the literal form of language itself in their rap lines. Their quality as a form of the spread is inherent to the mode of rap battles, which are, per definition, meant to dis(able). In this sense, the rap battle with his classmates constitutes the most intimate and direct version of the spread, in which no risk information is disclosed with incomprehensible speed (cf. above), but rap lines are. Adam, having understood at this point that he can employ language as a means of transporting himself beyond the debilitation these lines are meant to cause, now realizes that

... it didn't matter what words he was plugging into the machinery of syntax ... it didn't matter if it was rhyming about bitches or blow ... what mattered was that language, the fundamental medium of sociality, was being displayed in its abstract capacity ... (256)

Not only is language a tool that can be used to spread others in a sublimely overwhelming flurry of words, but it also constitutes salvation from a debilitating situation in which one faces the sublime. For a subject facing this, looking for words that they know in a situation that displaces them into a 
negative world of whose lexicon they can, by definition, not know a single entry, is a daunting task, but the only viable way out. Adam has, at this point, mastered this, and is in awe of the new agency he discovered how to gain.

Complementing this power of language, there seems to be a two-dimensional spectrum of which Adam and Darren occupy two different directions, both of which coincide with the spheres of the sublime: vertically and horizontality ${ }^{[3]}$ Adam, at the lake neighborhood, "was looking up at himself looking down. Then he could toggle rapidly between these perspectives, these scales, in a relay that unfixed him from his body" (11). Adam's cognitive abstraction and the occupation of a vantage point, which lets him re-place himself both at the party and within the confusing sameness of the lakeside mansion, enable him to simultaneously be a part of the scene and examine himself and his surroundings from afar. His mind reels heavenward, and he gazes at the scene from above. Now, when it is his turn to rhyme at the party, he "rises above the stupid violence of the battles" (256). Using grammar as a tool for navigating his way out of the spread, he is all the more able to construct his own responses and rap lines, and he peeks into the transcendent sphere at will, catching "a glimpse, however fleeting, of grammar as pure possibility" (269).

Darren, however, can only muster a "clumsy attempt to repeat word for word what Adam chanted about fists in faces and catching cases" (256-57). He is not able to take a loftier vantage point, and subsequently is left to experience only the debilitating force of the sublime. The same as when he walks through rural Kansas on foot, both literally and figuratively searching for his way on a horizontal axis - submerged in its oppressive repetitiveness - whichever way he goes thereon, it leads him back to wherever he already is. In this context, Goodhart's assessment of Trumpian subjects $^{[4]}$ as somewheres, who, according to Wendy Brown, "cling to the soil, even if it is planted in suburban lawn devastated by ... terminal futures," (187) gains a figurative relevance for what Darren experiences if it is juxtaposed with Adam's loftiness. However, the displacing logic of the sublime Lerner's novel assigns to such suburban environments would suggest a modification of Brown's terminology for its inhabitants. Rather than somewheres, they become pseudosomewheres, like Darren, holding on to the illusion of being somewhere only by admitting their own displacement, and a subsequent re-placement threatens their subjectivity in both a metaphysical and an identitarian sense. This adds to the novel's illustration of Darren's experiences as 
constitutive of a perception of a place that molds an identity equally unnuanced as the physical spaces that sublimely overwhelm Darren.

Once more, Darren finds himself lost for words in the face of the spread. This, of course, forms the antithesis to Adam's rapture, and his failure to react to the rap lines or adopt their spreading mode at his will as an equal foreshadows his complete debilitation. Instead of, like Adam, abstracting his perception and his reactions to the spread, he resorts to a physical externalization of his ability in order to defy debilitation - later that night, the jovial jocks he had been rapping with shortly before provoke Darren, who snaps and severely injures a girl by throwing a billiard ball at her head and is subsequently arrested.

What, for Adam, becomes an endless source of creative reflection and placement of himself within suburban America, becomes an overwhelming array of emotions canalized into frustration for Darren. The sublime that comes in the guise of intimacy and familiarity takes off its mask of looming over present things in Topeka - houses, tree patches, McMansions, protein shakes, parties, Hypermarts, all little more than just the same as the ones before them, after them, or next to them - revealing something that is nothing and seemingly leads nowhere. The only way out - or somewhere at all - becomes seizing the agency for oneself in a situation that has established the stark opposite of where one feels more at home.

Fast-forward into the late 2010s, Adam has made his peace with the fact that this threat is never ending. He finds a pressing need for his abstractions recurring when the narration jumps into the present time where he is a writer in New York City. Some twenty years after Topeka, "the twentyfour-hour news cycle, Twitter storms, algorithmic trading, spreadsheets" (see above) play the very same incessant, overwhelming role which the Lake Sherwood mansions had played back then. He slips into an argument with a man not paying any attention to his disruptive son on a playground, and instead stoically stares at his phone (cf. 265-70). This man turns out to be another Darren, who, maybe unable of anything else, condones his son's behavior when he forbids Adam's daughters to ride on the slide. Aside from the change of scenery to the Upper West Side, the novel in this scene provides another backdrop by interspersing Donald Trump quotes into the narrative, so that now the sublime confrontation is not the scenery of Kansas town, but an endlessly 
repetitive Twitter feed rolling - spreading - along on a giant barrel, another illusion of movement: "(I helped create her, Ivanka, my daughter)" (270).

In the last part of the novel, Adam and his family protest the Trump administration and its ICE policies (275-82). Again, he raises his voice to take a stand against the spread, the sublime other he is immersed in, and which now threatens not only him but also his daughters. Along with the other protesters, they form a human microphone - several people shouting something to circumvent permissions needed to carry megaphones at rallies: "It embarrassed me," he says, "it always had, but I forced myself to participate, to be part of a tiny public speaking, a public learning slowly how to speak again, in the middle of the spread" (270). They put their hopes into their voices as pure possibility, much like Adam, when he was in a rap battle some twenty years earlier. In trying to place himself and his family in an environment that must not be spread by an orange president - Morton's "expressionist parade of uncanny, clownlike objects" (226) - when everything always already is - "(Because when you're a star, they let you do it. You can do anything. You have the authority)" (270) — he finds that by assuming a voice when immersed into the utter negative, there may be a short relief from it to bring back into the positive, a fleeting glimpse of knowing what it would feel like to stand somewhere where one can never stand. Yet, this sense of placement that eventually buds, turns out to be nothing but another displacement, and trying to summon the United States that does not suffocate you with its Twitter feeds in a country that only knows the Trumpian spread merely exacerbates the estrangement as if the protesters were shouting at themselves, as if Adam was condemned to whispering into his own ear from above: "I don't know where you are, but You Are Not Here, and I won't stop talking before you are somewhere."

\section{Works Cited}

Arias-Maldonado, Manuel. "A Genealogy for Post-Truth Democracies: Philosophy, Affects, Technology." ECPR General Conference, Hamburg, Germany, 22-25 Aug. 2018, 2018, RiUMA, riuma.uma.es/xmlui/handle/10630/16392.

Baker, David. "The Sublime: Origins and Definitions." The Georgia Review, vol. 58, no. 2, 2004, pp. 303-09. 
Brown, Wendy. In the Ruins of Neoliberalism: The Rise of Antidemocratic Politics in the West. Columbia U P, 2019.

Day, John. "The Topeka School by Ben Lerner review - in a class of its own." The Guardian, 8 Nov. 2019, www.theguardian.com/books/2019/nov/08/the-topeka-school-by-ben-lerner-review. Accessed 1 June 2020.

Goodhart, David. The Road to Somewhere. The Populist Revolt and the Future of Politics. Hurst and Co., 2017.

Hallberg, Garth Risk. "Ben Lerner's 'The Topeka School' Revisits the Debates of the '90s." The New York Times, 3 Oct. 2019, www.nytimes.com/2019/10/03/books/review/topeka-school-benlerner.html. Accessed 1 June 2020.

Hultgren, John. "Undoing the Oikos, Awakening Resistance? Neoliberalism, Democracy, and the Environment in 'Trump Country'." Theory \& Event, vol. 23, no. 1, 2020, pp. 271-96.

Kant, Immanuel. Critique of Judgment. Translated by Werner S. Pluhar, Hacket Publishing Company, 1987.

Lerner, Ben. The Topeka School. Granta Books, 2019.

Morton, Timothy. "Sublime Objects." Speculations, vol. 2, 2011, pp. 207-27.

Preston, Alex. "The Topeka School by Ben Lerner Review - A Work of Extraordinary Intelligence." The Guardian, 5 Nov. 2019, www.theguardian.com/books/2019/nov/05/the-topeka-school-benlerner-review. Accessed 1 June 2020.

Pseudo-Longinus. On the Sublime. Edited and translated by William Rhys Roberts, 2nd ed., Cambridge University Press, 1907.

Russell, Donald Andrew. Introduction. On the Sublime, edited by Donald Andrew Russell, Clarendon Press, 1964, pp. ix-I.

Shelley, Percy Bysshe. "Mont Blanc. Lines Written in the Vale of Chamouni." The Complete Poetry of Percy Bysshe Shelley, edited by Donald H. Reiman et al., vol. 3, Johns Hopkins University Press, 2012, pp. 79-89. 


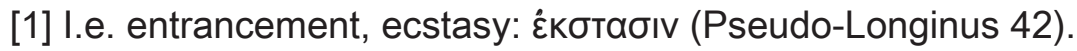

[2] I use might her with reference to Kant: "And it is only by presupposing this idea within us, and by referring to it, that we can arrive at the idea of the sublimity of that being who arouses deep respect in us, not just by his might as demonstrated in nature, but even more by the ability, with which we have been endowed, to judge nature without fear and to think of our vocation as being sublimely above nature" (Kant 123; par. 28; emphasis added). While Kant here refers to a Deity as the force behind the sublime, what would be more appropriate in this context would be to apply this reasoning to culture as such a mighty force if we consider the similarities between Kant's sublime nature and the cultural objects of the spread outlined above (cf. p. 1).

[3] For a subsumption of these axes within the concept of the sublime, especially in American cultural history, see Baker (307-09).

[4] The term somewhere in the context of post-truth society was first coined by David Goodhart in his 2017 book The Road to Somewhere. My linking of somewheres and Trumpian subjects draws on the connection between these terms that Hultgren makes in "Undoing the Oikos."

Creative Commons Attribution-NonCommercial-NoDerivatives 4.0 International License 